\title{
Pengaruh Penambahan Koro Benguk terhadap Sifat Organoleptik Soyghurt (Yoghurt Susu Kedelai)
}

\author{
Heni Purwantia ${ }^{\mathrm{a}, 1, *}$ \\ a SMK Negeri 4 Yogyakarta, Jl. Sidikan No 60 Yogyakarta, 55161, Indonesia \\ ${ }^{1}$ henipurwanti_skmn4@yahoo.com \\ * penulis korespondensi
}

\begin{abstract}
Soy milk contains elements that are almost the same as cow's milk, therefore soy milk can also be fermented into soybean yogurt or referred to as soyghurt. This research experiment aims to determine the effect of the addition of koro benguk on the nature of organoleptic soyghurt. Koro benguk is one of the beans that is less popular than the other types because of some traits of the prone koro benguk which are not liked by consumers. The treatment carried out in this study is the comparison of soybeans and velvet koro benguk in making soyghurt. Variations made are the comparison of soybeans and koro benguk with a ratio of 80:20, 60:40, 40:60. The results of the analysis with variance analysis showed that the addition of koro benguk in making soyghurt had a real influence on the organoleptic properties of Soyghurt in the form of color, texture, aroma and taste. The DMRT test showed that the comparison of the 80:20 koro benguk soybean was generally not significantly different from soybean soybean pure as a control and had a preferred level of preference
\end{abstract}

Keywords: koro benguk, organoleptic, soyghurt

ABSTRAK

Susu kedelai mengandung unsur-unsur yang hampir sama dengan susu sapi, oleh karena itu susu kedelai juga dapat difermentasi menjadi yoghurt kedelai atau disebut dengan nama soyghurt. Penelitian eksperimen ini bertujuan untuk mengetahui pengaruh penambahan koro benguk terhadap sifat organoleptic soyghurt. Koro benguk merupakan salah satu kacang-kacangan yang kurang popular dibanding jenis yang lain karena beberapa sifat koro benguk yang tidak disukai konsumen. Perlakuan yang dilakukan pada penelitian ini adalah perbandingan kedelai dan koro benguk pada pembuatan soyghurt. Variasi yang dilakukan adalah perbandingan kedelai dan koro benguk dengan perbandingan 80:20, 60:40, 40:60. Hasil penelitian dengan analisa varian menunjukkan bahwa penambahan koro benguk pada pembuatan soyghurt memberikan pengaruh nyata terhadap sifat organoleptic soyghurt berupa warna, tekstur, aroma dan rasa. Uji DMRT menunjukkan perbandingan kedelai koro benguk 80:20 secara umum tidak berbeda nyata dengan soyghurt kedelai murni sebagai kontrol dan mempunyai tingkat kesukaan disukai.

Kata Kunci: koro benguk, organoleptik, soyghurt

\section{Pendahuluan}

Yoghurt merupakan salah satu produk susu yang mempunyai rasa asam segar karena dibuat dengan cara fermentasi susu. Yoghurt adalah makanan hasil fermentasi susu oleh bakteri asam laktat yang mempunyai cita rasa khas. Bahan dasar pembuatan yoghurt adalah susu murni dari berbagai hewan mamalia, susu skim, susu full cream, susu kedelai, susu kecipir, atau campuran dari beberapa bahan tersebut (Rahayu, dkk., 1989). 
Kandungan asam pada yoghurt yang cukup tinggi, sedikit atau tidak mengandung alkohol sama sekali, mempunyai tekstur semi padat atau smooth, kompak serta mempunyai rasa asam yang segar.

Selama ini bahan dasar pembuatan yoghurt masih banyak menggunakan susu sapi, baik susu segar full cream maupun skim. Komponen terpenting dalam bahan dasar yoghurt adalah protein sebagai agen pembentukan koagulasi, sehingga prosentase protein berpengaruh langsung terhadap kekentalan / viskositas yoghurt. Komposisi penting lainnya adalah laktosa yang berfungsi sebagai sumber energi bagi mikroorganisme penghasil rasa masam (Muis, 1996).

Dalam pembuatan yoghurt secara alami, susu yang akan difermentasi dipanaskan $90^{\circ}$ C selama 15-30 menit, kemudian didinginkan sampai $43^{\circ} \mathrm{C}$, diinokulasi dengan $2 \%$ kultur campuran lactobacillus bulgaricus dan streptococcus thermophillus kemudian dibiarkan pada suhu $43^{\circ} \mathrm{C}$ selama kira-kira 3 jam sampai tercapai keasaman yang dikehendaki (biasanya sekitar 0,85-9,90\%) dan $\mathrm{pH}$ 4,0 sampai dengan 4,5. Setelah tercapai kondisi yoghurt yang diinginkan, kemudian yoghurt didinginkan sampai suhu mencapai $5^{\circ} \mathrm{C}$ untuk dikemas (Buckle, dkk., 1987).

Untuk mendapatkan yoghurt yang baik, diperlukan bahan dasar susu yang mempunyai kandungan zat padat sebesar 19-20\%. Kandungan zat padat susu segar sebesar $10 \%$ sehingga perlu diuapkan sebagian air dalam susu bubuk sebesar 4-5\% dalam bentuk skim atau atau full cream. Zat padat dalam susu berperan untuk pembentukan tekstur dan aroma yoghurt yang baik. Kandungan zat padat dalam susu yang optimal sebesar 15,5-16,6\% (Tamine, dkk., 1980).

Selain susu sapi, yoghurt juga dapat diolah dengan menggunakan bahan dasar susu kedelai. Susu kedelai mengandung unsur-unsur yang hampir sama dengan susu sapi. Oleh karena itu, susu kedelai juga dapat difermentasi menjadi yoghurt kedelai atau disebut dengan nama soyghurt. Dalam pembuatan soyghurt, yang perlu diperhatikan adalah jenis karbohidrat dalam susu kedelai sangat berbeda dengan karbohidrat dalam susu sapi. Karbohidrat dalam susu kedelai terdiri atas golongan oligosakarida dan poligosakarida yang tidak dapat dicerna secara langsung sebagai sumber energy. Sedangkan karbohidrat pada susu sapi adalah golongan laktosa, yang tergolong dalam disakarida dan merupakan gula yang lebih sederhana dibanding polisakarida (Koswara, 1995).

Koro benguk merupakan jenis kacang-kacangan yang belum banyak pemanfaatannya, karena proses pengolahan yang sulit menyebabkan koro benguk di Indonesia kurang populer dibandingkan kacang-kacangan yang lain. Koro benguk merupakan komoditi lokal yang pembudidayaan sangat mudah, sehingga jumlahnya melimpah dan masih terbatas jumlah dan variasi olahannya menjadi salah satu peyebab rendahnya harga koro benguk dibanding harga kedelai. Sebaliknya kebutuhan kedelai di Indonesia sangat tinggi, sehingga harus dicukupi dengan import dari negara lain. Untuk mengatasi ketergantungan kebutuhan kedelai maka perlu dilakukan penambahan koro benguk pada pembuatan soyghurt. Jika dibandingkan dengan kedelai, kandungan protein dan lemak koro benguk lebih rendah tetapi karbohidrat dan seratnya lebih besar sehingga berpotensi dalam penanggulangan penyakit degenerative (Handayani, dkk., 1996 dalam Amanah dkk, 2019). Menurut Anonim, (1981) dalam Meta Mahendradatta (1990), kandungan protein koro benguk adalah 24 gram / 100 gram cukup potensial sebagai sumber protein. 
Dengan demikian koro benguk berpotensi untuk dikembangkan menjadi bebagai olahan makanan yang akan memperkaya khasanah kuliner Indonesia.

Biji koro benguk mengandung mengandung asam sianida $(\mathrm{HCN})$ yang besifat racun sebesar $0,01 \%$. Namun pengaruh HCN tersebut bisa dibuang dengan merendam koro benguk ke dalam air bersih selama 24-48 jam (tiap 6-8 jam airnya diganti) sudah menjamin hilangnya zat racun HCN (Kasmidjo, R.B., !990) Menurut Pramita dkk., (2008) dalam Yuni Safaratul Amanah, dkk., (2019), kandungan asam sianida pada koro benguk dapat dikurangi dengan cara perendaman. Penelitian Arif Nurmawan Toro, dkk., (2014) menyebutkan perendaman koro benguk dalam air kapur lebih efektif menetralkan HCN dibanding dengan perendaman dalam air, sehingga koro benguk tidak mengandung HCN dan aman dikonsumsi.

\section{Metode Penelitian}

\subsection{Bahan dan Alat}

Bahan yang digunakan dalam pembuatan soyghurt antara lain : koro benguk varietas abu-abu, kedelai varietas Willis yang mempunyai warna kulit biji kuning, susu skim, gula halus, gelantin, inoculum Lactobacillus bulgaricus dan Streptococcus thermophillus.

Peralatan yang digunakan untuk membuat soyghurt antara lain : panci email, timbangan, baskom plastic, kain saring, sendok atau pengaduk, kompor, blender, thermometer, incubator dan gelas plastik. Peralatan yang digunakan untuk uji organoleptic antara lain : kertas kuisioner dan alat tulis.

\subsection{Pembuatan Yoghurt Susu Kedelai}

Cara kerja dimulai dari pembuatan soyghurt kontrol yaitu shoyghurt bahan dasar kedelai murni, kemudian selanjutnya pembuatan soyghurt dengan penambahan koro benguk perbandingan 80:20, 60:40, 40:60 yang langkah-langkah mengikuti diagram alir pembuatan soyghurt berikut ini: 


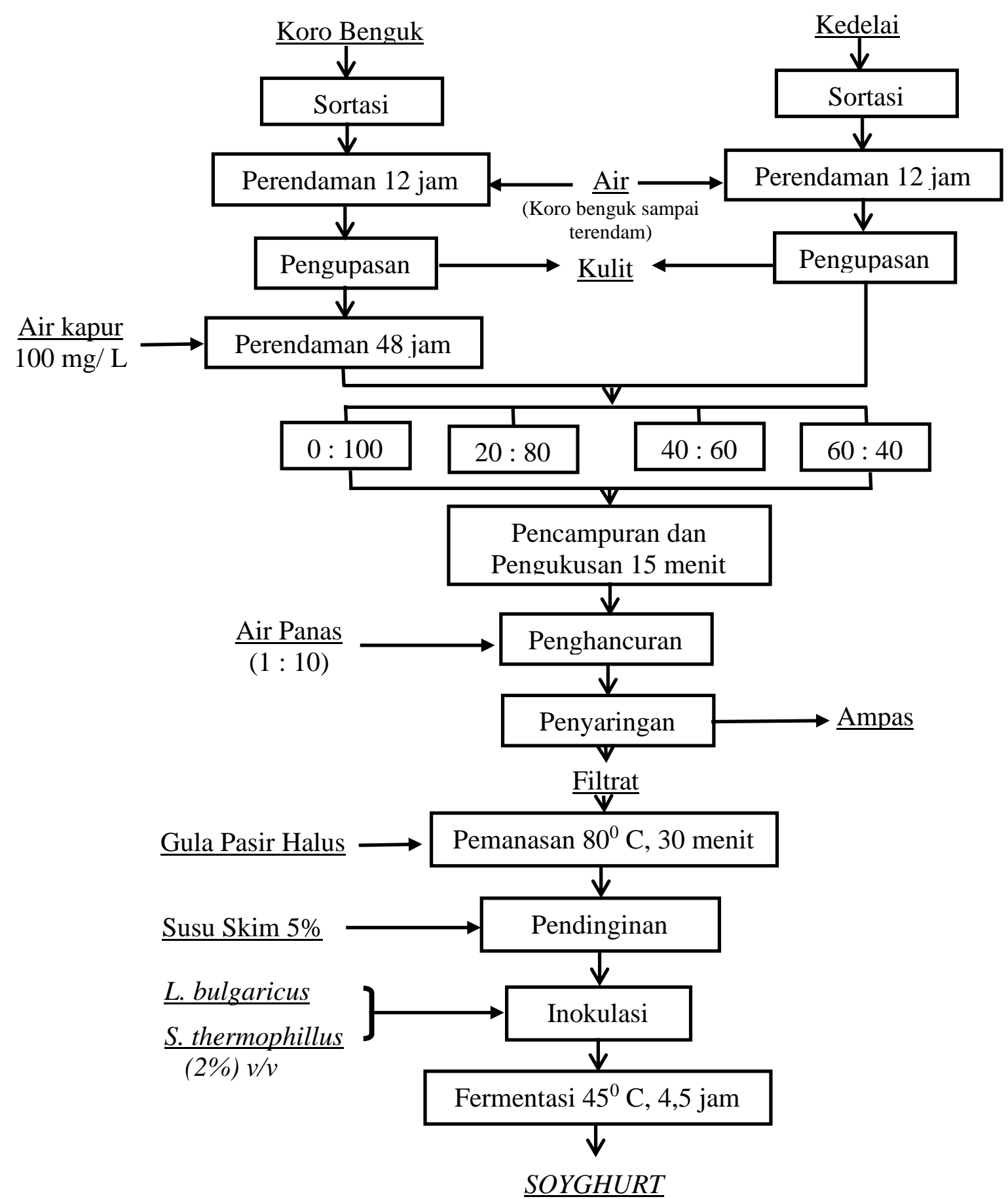

Gambar 2.1. Diagram Alir Proses Pembuatan soyghurt dengan Penambahan Koro Benguk

\subsection{Rancangan Penelitian}

Untuk mengetahui pengaruh penambahan koro benguk terhadap sifat organoleptik soyghurt (yoghurt susu kedelai), maka digunakan Rancangan Percobaan Blok Acak Lengkap (Randomized Complete Block Design) untuk uji sensoris yang meliputi warna, tekstur, rasa, aroma dan kesukaan total dengan panelis semi terlatih (mahasiswa) sebanyak 20 orang. 


\section{Hasil dan Pembahasan}

Berikut ini adalah tabel hasil pengujian soyghurt oleh panelis semi terlatih, secara umum berdasarkan analisis organoleptic, soyghurt dengan perlakuan penambahan koro benguk sebesar $0 \%$ (A), 20\% (B), 40\% (C), dan 60\% (D).

Tabel 3.1. Hasil Uji Organoleptic Terhadap Soyghurt Penambahan Koro Benguk

\begin{tabular}{|c|c|c|c|c|c|}
\hline Tipe Uji & A $(0 \%)$ & B $(20 \%)$ & $\mathrm{C}(40 \%)$ & $\mathrm{D}(60 \%)$ & Keterangan \\
\hline Warna & $1,40^{\mathrm{a}}$ & $2,30^{\mathrm{b}}$ & $4,00^{\mathrm{c}}$ & $5,40^{\mathrm{d}}$ & $\begin{array}{l}\text { 1. Putih susu } \\
\text { 2. Putih agak kuning } \\
\text { 3. Putih kecokelatan } \\
\text { 4. Cokelat } \\
\text { 5. Cokelat kebiruan }\end{array}$ \\
\hline Tekstur & $2,30^{\mathrm{e}}$ & $2,35^{\mathrm{ef}}$ & $2,50^{\mathrm{fg}}$ & $3,00^{\mathrm{g}}$ & $\begin{array}{l}\text { 1. Sangat kokoh } \\
\text { 2. Kokoh } \\
\text { 3. Agak kokoh } \\
\text { 4. Lunak } \\
\text { 5. Lunak berair }\end{array}$ \\
\hline $\begin{array}{l}\text { Aroma } \\
\text { asam }\end{array}$ & $3,40^{\mathrm{h}}$ & $3,25^{\mathrm{hi}}$ & $3,15^{\mathrm{ij}}$ & $2,80^{\mathrm{j}}$ & $\begin{array}{l}\text { 1. Sangat tajam } \\
\text { 2. Tajam } \\
\text { 3. Agak tajam } \\
\text { 4. Tidak tajam } \\
\text { 5. Sangat tidak tajam }\end{array}$ \\
\hline Rasa & $2,95^{\mathrm{k}}$ & $2,85^{\mathrm{k}}$ & $2,85^{\mathrm{k}}$ & $2,80^{\mathrm{k}}$ & $\begin{array}{l}\text { 1. Sangat asam manis } \\
\text { 2. Manis, asam sekali } \\
\text { 3. Asam manis } \\
\text { 4. Agak asam manis } \\
\text { 5. Manis tidak asam }\end{array}$ \\
\hline
\end{tabular}

Tabel 3.1. merupakan hasil pengujian scoring soyghurt dengan penambahan koro benguk. soyghurt kedelai murni (A) sebagai kontrol yang mempunyai sifat putih susu agak kekuningan $(1,40)$, dengan tekstur kokoh $(2,30)$, aroma asam yang agak tajam $(3,40)$ dan rasa asam manis $(2,95)$ karena hasil dari fermentasi bakteri asam laktat.

Analisis varian menunjukkan adanya pengaruh nyata antara perlakuan. Nilai warna soyghurt bervariasi sekitar antara putih agak kuning sampai cokelat (1,4-5,6). Uji Duncan's Multiple Range Test (DMRT) pada taraf significant 5\% menunjukkan soyghurt dari kedelai murni sebagai control (A) berbeda nyata dengan soyghurt dengan penambahan koro benguk sebesar (B) 80:20, (C) 60:40 dan (D) 40:60. Soyghurt B tidak berbeda nyata dengan soyghurt $\mathrm{C}$ tetapi berbeda nyata dengan soyghurt $\mathrm{D}$. Antara soyghurt $\mathrm{C}$ dan $\mathrm{D}$ berbeda nyata.

Penambahan koro benguk pada soyghurt memberikan pengaruh nyata terhadap penilaian warna oleh panelis. Semakin besar jumlah koro benguk yang ditambahkan mengakibatkan semakin nyata timbulnya warna gelap (cokelat). Menurut Tranggono (1989), menyebutkan perubahan warna pada koro benguk karena reaksi pencokelatan non enzimatik baik reaksi fisi, dehidrasi kuat maupun dehidrasi lemah dihasilkan senyawa pra 
melanoidin yang larut dalam air. Senyawa ini antara lain: pirivaldehide, diasetil, furfural, dehidrofurfural, redukton dan dehidro redukton.

Pengujian terhadap tekstur soyghurt menunjukkan adanya pengaruh nyata antara masingmasing perlakuan. Nilai tekstur berkisar antara 2,3 sampai 3 yaitu antara kokoh sampai agak kokoh. Uji DMRT $5 \%$, menunjukkan soyghurt kontrol tidak berbeda nyata dengan soyghurt B, tetapi berbeda nyata dengan soyghurt C dan D. Soyghurt B tidak berbeda nyata dengan soyghurt $\mathrm{C}$ tetapi berbeda nyata dengan soyghurt D. Soyghurt $\mathrm{C}$ dan D tidak berbeda nyata.

Fermentasi dalam pembuatan soyghurt akan terbentuk asam laktat sehingga protein susu menggumpal membentuk gel soyghurt. Penggumpalan tersebut terjadi karena protein mengalami denaturasi (Winarno, 1995). Tekstur gel soyghurt kontrol mempunyai skor tidak berbeda nyata dengan soyghurt B dan memberikan tekstur yang kokoh. Sedangkan soyghurt C dan D menunjukkan tekstur yang agak kokoh. Tekstur gel soyghurt terbentuk semi solid (setengah padat) dan menentukan tekstur yoghurt, tekstur yoghurt dipengaruhi oleh kadar protein bahan (Koswara, 1995).

Hasi pengujian DMRT 5\% terhadap aroma soyghurt menunjukkan adanya perbedaan yang nyata diantara masing-masing perlakuan. Nilai berkisar antara 2,80 sampai dengan 3,40 yang berarti antara tajam sampai agak tajam. Soyghurt control tidak berbeda nyata dengan soyghurt B, tetapi berbeda nyata dengan soyghurt C dan D. Soyghurt B tidak berbeda nyata dengan $\mathrm{C}$ tetapi berbeda nyata dengan $\mathrm{D}$, sedangkan antara $\mathrm{C}$ dan $\mathrm{D}$ tidak berbeda nyata. Sedangkan untuk pengujian DMRT 5\% terhadap rasa soyghurt menunjukkan tidak adanya perbedaan yang nyata diantara masing-masing perlakuan. Penilaian panelis berkisar antara angka 2,80 sampai dengan 2,95 yang memberi arti rasa soyghurt adalah asam manis.

Menurut Koswara (1995), selain berperan dalam pembentukan gel yoghurt, asam laktat juga memberikan ketajaman rasa asam dan menimbulkan aroma khas yoghurt. Rasa dan aroma merupakan sifat kesatuan pada soyghurt yang saling menunjang, karena memang keduanya merupakan akibat adanya asam laktat pada produk. Rasa dan aroma pada soyghurt merupakan komponen yang paling perlu diperhatikan karena merupakan kunci yang dinilai oleh panelis. Pada penelitian ini menunjukkan bahwa semakin banyak penambahan koro benguk pada soyghurt akan memberikan warna yang semakin gelap (kecokelatan) pada soyghurt dan tidak disukai oleh panelis, hal ini dipengaruhi oleh reaksi enzimatis yang terjadi pada koro benguk. Selain warna yang semakin gelap, semakin banyak penambahan koro benguk pada soyghurt juga mengakibatkan aroma dan rasa soyghurt semakin tajam sifat asamnya. Rasa asam yang berlebih karena kadar karbohidrat koro benguk yang lebih tinggi dibanding kedelai diduga merupakan penyebab aroma alcohol (asam) pada soyghurt dengan penambahan koro benguk yang lebih banyak (Ganjar, 1977 dalam Mahendradata, 1990). 
Tabel 3.2. Hasil Uji Kesukaan Total Terhadap Soyghurt Penambahan Koro Benguk

\begin{tabular}{|c|c|c|c|c|c|}
\hline Tipe Uji & $\mathrm{A}(0 \%)$ & B (20\%) & C (40\%) & $\mathrm{D}(60 \%)$ & Keterangan \\
\hline Kesukaan & $3,85^{1}$ & $3,7^{(1}$ & $3,0^{\mathrm{m}}$ & $2,25^{\mathrm{n}}$ & 1. Sangat tidak suka \\
\hline Total & & & & & 2. Tidak suka \\
\hline & & & & & 3. Agak suka \\
\hline & & & & & 4. Suka \\
\hline & & & & & 5. Suka sekali \\
\hline & & & & & 6. Sangat suka sekali \\
\hline
\end{tabular}

Hasil pengujian kesukaan total (Hedonic Test) (Tabel 3.2.) menunjukkan pengaruh nyata antara perlakuan. Nilai kesukaan berkisar antara tidak suka $(2,25)$ sampai suka $(3,85)$. Uji DMRT 5\% menunjukkan bahwa soyghurt control (A) dengan soyghurt (B) tidak ada perbedaan nyata dari kisaran angka 3,85 (A) dan 3,70 (B) yang disukai oleh panelis, sedangkan untuk soyghurt C agak disukai oleh panelis. Soyghurt D tidak disukai oleh panelis dengan komentar panelis karena warna soyghurt lebih gelap (cokelat) dan teksturnya yang kurang kompak (pecah-pecah). Tekstur yang pecah-pecah dimungkinkan karena kandungan protein koro benguk lebih rendah dibanding kedelai.

\section{Kesimpulan}

Dari ketiga variasi perbandingan kedelai dan koro benguk yang sudah dilakukan dapat ditarik kesimpulan bahwa penambahan koro benguk pada pembuatan soyghurt memberikan pengaruh terhadap sifat organoleptic soyghurt berupa warna, tekstur, aroma dan rasa. Perbandingan kedelai koro benguk 80:20 secara umum tidak berbeda nyata dengan soyghurt kontrol.

\section{Pustaka}

Amanah, Yuni Safaratul, dkk. 2019. "Kadar Protein dan Tekstur pada Tempe Koro Benguk dengan Substitusi Kedelai hitam", dalam Jurnal Pangan dan Gizi. Vol. 9, No. 2: 69-78.

Anonim. 1981. Daftar Komposisi Bahan Makanan. Bhatara Karya Aksara. Direktorat Gizi, Departemen Kesehatan Republik Indonesia.

K.A., Buckle dkk. 1987. Ilmu Pangan. Universitas Indonesia, Jakarta.

Kasmidjo, R.B. 1990. Tempe: Mikrobiologi dan Biokimia Pengolahan Serta Pemanfaatannya. Yogyakarta: Pusat Antar Universitas Pangan dan Gizi UGM.

Koswara. 1995. Teknologi Pengolahan Kedelai. Yogyakarta: Pustaka Usaha, Bernas, Yogyakarta.

Mahendradata, Meta. 1990. Aktivitas Fitase Selama Proses Pembuatan Tempe Kara Benguk, Gude, dan Kara Putih Menggunakan Inokolum Tradisional (Usar). Skripsi. Fakultas Teknologi Pertanian UGM Yogyakarta.

Muis, Abdul. 1996. Potensial Santan Kelapa Sebagai Bahan Dasar Alternatif Pembuatan Yoghurt. Skripsi. TPHP, FTP UGM Yogyakarta. 
Rahayu, Kapti dan Slamet Sudarmadji. 1989. Mikrobiologi Pangan. Yogyakarta: PAU Pangan dan Gizi, UGM.

Tamine, A.Y. dan H.C. Deeth. 1980. "Yoghurt Nutritive and Therapentic Aspect", dalam Journal Food Protection. Vol. 44, No. 1: 78-86.

Toro, dkk. 2014. Pengaruh Lama Perendaman Koro Benguk (Mucuna pruriens) Dalam Air Kapur $\left(\mathrm{Ca}(\mathrm{OH})_{2}\right.$ Terhadap Kadar HCN (Asam Sianida), dalam Jurnal Teknologi Laboratorium. Vol. 3, No. 2: 97-102.

Tranggono. 1989. Perubahan Sifat Protein Koro Benguk Akibat Perlakuan Perendaman, Suhu, dan pH. Laporan Penelitian. FTP-UGM Yogyakarta.

Winarno, F.G. 1995. Enzim Pangan. Jakarta: Gramedia Pustaka Utama. 